\title{
Process Modeling and Public Value: Performance Measurement for Emergency Assistance Services?
}

\author{
Claude Rochet ${ }^{1}$, Anaïs Saint ${ }^{1}$, Bruno Tiberghien ${ }^{1}$, Philippe Agopian ${ }^{2}$, Catherine Paris-Laporte ${ }^{2} \&$ Valéry \\ Soulleihet ${ }^{2}$ \\ ${ }^{1}$ Institut de Management Public et Gouvernance Territoriale (IMPGT), Centre d'Etudes et de Recherche en \\ Gestion d'Aix-Marseille (CERGAM), Aix Marseille Université, France \\ ${ }^{2}$ Service Départemental d'Incendie et de Secours des Bouches du Rhône (SDIS 13), France \\ Correspondence: Bruno Tiberghien, 21 rue Gaston de Saporta, 13625 Aix-en-Provence Cedex 1, France. Tel: \\ 33-4-4217-0587. E-mail: bruno.tiberghien@univ-amu.fr
}

Received: May 25, $2012 \quad$ Accepted: June 7, $2012 \quad$ Online Published: December 31, 2012

doi:10.5539/ibr.v6n2p137 URL: http://dx.doi.org/10.5539/ibr.v6n2p137

\begin{abstract}
This paper proposes a process modeling of a cerebrovascular accident (CVA) channel, according to the Business Process Modeling Notation (BPMN) rules, in order to build a balanced scorecard (BSC). The Fire department in the Bouches-du-Rhône (SDIS) and the medical emergency service have coordinated their action and processes with hospitals to set up this kind of specific channel to deal with strokes. According to Hankey and Warlow (1999), each year in a population of 1 million inhabitants of a developed country, 2400 patients use a care institution because of this pathology. As the window of opportunity for treatment is only 4 hours from first symptoms, swiftness is needed in both diagnosis and intervention. This emphasizes the fluidity of the channel, and thus the coordination of actors, as key success factors. This work upon process modeling is a source of lessons on the role of the information system in organizational innovation in the public services and the required capabilities to be mastered. But it mainly allows us to bring out the relevant indicators to build up the monitoring part of the balance scorecard (BSC) and to propose a roadmap to implement such a method for equivalent medical channels.
\end{abstract}

Keywords: process modeling, Information System, CVA channel, stroke units, performance measurement, balanced scorecard

\section{Introduction}

This paper presents the process modeling of relieving people in case of a stroke - cerebrovascular accident (CVA) - in order to build a balanced scorecard (BSC). The Fire department in the Bouches-du-Rhône (SDIS) and the medical emergency service have succeeded in coordinating their action and processes with hospitals to set up a specific channel to deal with these accidents. The stake is important since if the relevant medical intervention is carried about within four hours, the patient may be discharged from hospital without sequels.

We present the global modeling of the channel operation with processes, subprocesses and modeled according to the BPMN rules: first call, arrival on site, teleconference between rescue staff and medical emergencies for a first diagnosis, and - if a CVA is suspected - transfer of the patient to the appropriate neurovascular unit. This modeling allows us to bring out the relevant indicators to build up the monitoring part of the balance scorecard (BSC). To draw a balance between costs and benefits for the society as a whole, we adopt a three levels vision of the process:

- COST: What is the cost of this rescue channel compared to a classical one?

- MANAGEMENT: What are the impacts of this process on the Fire Department budget? What kind of organizational change is required? Regarding this process, how to join up public services that have been split in silos?

- IMPACT AND EXTERNALITIES: What are the costs saved for the health care system? What are the impacts on the quality of life of the relieved patient? How to evaluate the pertinence of such an approach? 
It is essential to put emphasis on the benefits for the society on the long term. Among the four hundred patients the SDIS transfers to the stroke center per year, $20 \%$ are eligible to this specific treatment: so it is actually possible to calculate the costs saved for the society if it took care of patients affected with irreversible disabilities. In the same move, this example sheds light on the usefulness of educating the public to recognize the pathology and to have the relevant behavior in phoning any emergency call center $(15,18$ or 112), and allows building the legitimacy of implementing such costly processes. This work upon process modeling is finally a source of lessons on the role of the information system in organizational innovation in the public services and the required capabilities to be mastered.

To conduct this study, a meticulous search through the literature has been essential to draw a status report, in the actual scientific publications, about the different topics treated: (information system, BPM approach, indicators...). Then, an important phase of observation has been carried out. Indeed, we conducted an abductive work, i.e. involving several back and forth between theory and fieldwork (Avenier \& Gavard-Perret, 2008) in order to produce sense thanks to comparisons (Charreire Petit \& Durieux, 2007). This method comes within the scope of a research-action approach due to the immersion, in the channel, of some researchers who directly work on the problem's resolution (Allard-Poesi \& Maréchal, 2007) -in this case on the process modeling and the creation of the balanced scorecard. However, this may imply a non-separability of the researcher and the object of study (Giordano \& Jolibert, 2008) and, therefore, an amplification of the bias effect due to the behavior of the actors in relation to the problem (Journé, 2008).

In this article, we first explain the overview and issues of the CVA channel. In a second part, the link with the information system is made and after presenting the modeled process and discussing the benefits of this approach to monitor the channel, we propose a roadmap to implement such a method for equivalent medical channels.

\section{Overview and Issues of a CVA Channel}

\subsection{Explanations about CVA}

Also called"stroke", a cerebrovascular accident (CVA) is a disturbance in the blood supply to the brain. It can be due to an arterial blockage or a hemorrhage. In both cases, the brain's cells are not oxygenated and die just after a few hours. Without treatment to avoid the death of these cells, the patient will suffer non-reversible diseases such as severe paralysis.

In France, in 2005, 150000 CVA were counted: it is equivalent of one stroke every four minutes! The average age of the victim is 73 years (Canaple \& Depriester, 2006). Moreover, CVA is the third cause of adult death in France. Because of the ageing of the population in European countries and the increase of high-risk population (obesity, cigarette, sedentary lifestyle...), we must expect the strokes to be more and more frequent. A French ministerial circular (Note 1) lists the consequences of CVA on the health care system in France: functional therapy, speech therapy, rehabilitation, social reintegration, home health aide, financial assistance, etc. In some cases, the patients could also need accommodations in extended care facilities. Because of these very expensive consequences, strokes have to be considered as a central public health issue (Canaple \& Depriester, 2006).

The lack of an appropriate treatment has for years made room for a"contemplative and wait-and-see attitude" (Canault, Castanier, Laude, Bonnefoi, \& Kiegel, 2006, p.23). But nowadays, and due to the development of magnetic resonance imaging, a treatment has been discovered. We can now detect an arterial blockage in the brain and dissolve the clot by thrombolysis. To be effective, this treatment needs to be applied within the four hours following the first symptoms of stroke (paralysis on one side of the body, aphasia, legs which steal/fall, paralysis on one side of the face, headaches (Anonymous, 2005)). When eligible ( $20 \%$ of cases) and subjected to this treatment, a patient can retrieve his normal health condition. In this channel, $90 \%$ of treated patients go back to normal life though none of the untreated ones do. Besides, the benefits of this treatment are irrespective of age, gender and seriousness of the stroke.

\section{What is a stroke center?}

$\checkmark$ A multi-disciplinary team (doctors, nurses, physical therapists, speech therapists, psychologists, physiotherapists, social workers...)

$\checkmark$ A permanent and facilitated access to a technical platform with MRI

$\checkmark \quad$ The ability to administer a thrombolysis 
In order to bring this treatment within potential patients' reach, the French circular of November 3rd, 2003, provides that the different emergency and medical actors would have to coordinate their action to create a specific CVA channel. The aim is to weave a territorial network so everywhere in the Bouches du Rhône a stroke could be efficiently taken into charge.

In mentioned region of France, there is only one stroke center (based in Marseille). That's why the Fire department in the Bouches-du-Rhône (SDIS) and the medical emergency will have to coordinate their processes with the stroke centers' so that an MRI (Note 2) will always be available for the victims of CVA in a short time. So, in partnership with the university, the Fire department initiated a process modeling approach in order to clarify the role of each actor in the channel and to extract performance indicators. These indicators will be useful to build up a balanced scorecard that will permit to monitor the channel in real time.

\subsection{Creation, Organization and Inventory of Stroke Channels in France}

As estimated by Hankey and Warlow (1999), each year, in a population of 1 million inhabitants of a developed country, 2400 patients use a care institution because of a first stroke $(n=1800)$ or a recurrent one $(n=600)$.

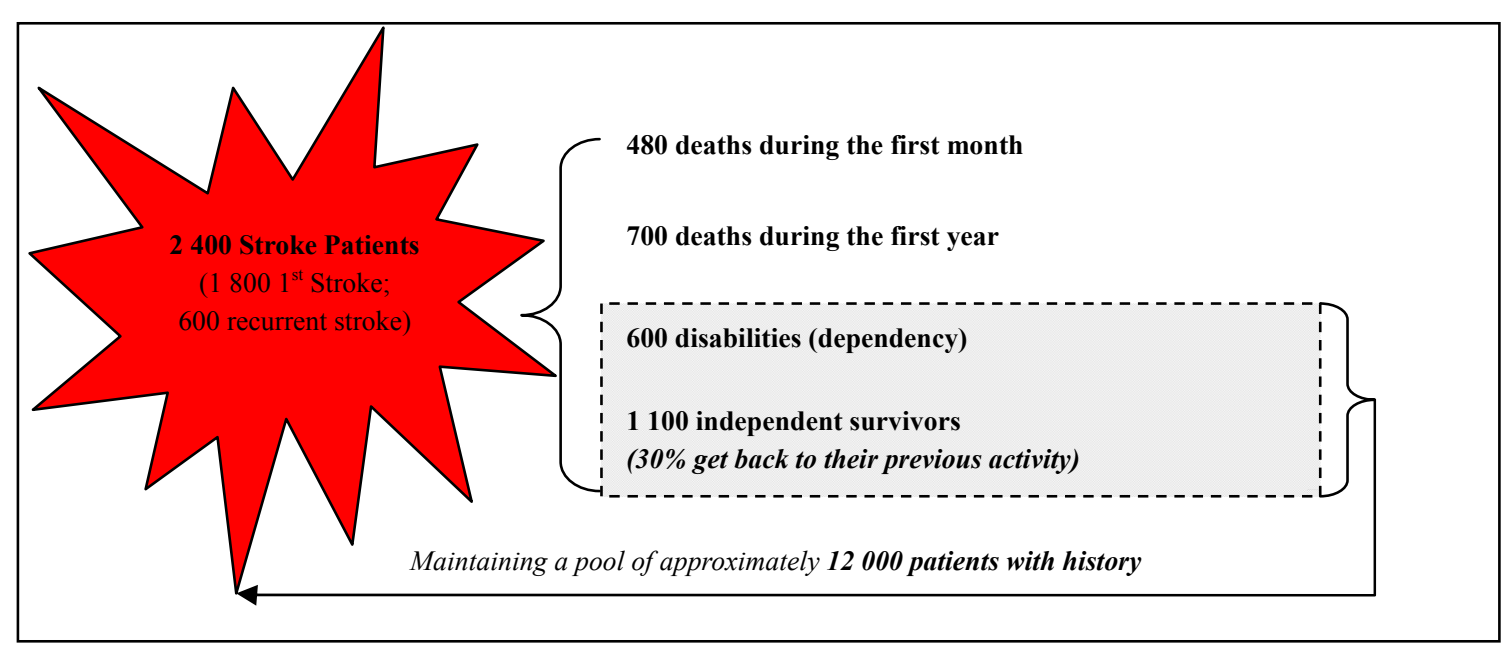

Figure 1. Estimated impact of stroke over 1 year, in a population of 1 million inhabitants of a developed country Source: adapted from Hankey and Warlow, 1999.

Based on this estimates and according to the French Neurovascular Society (SFNV, 2001), "the organization of stroke units avoids 1 death or disability for 20 patients treated, [... that is to say] 120 deaths or disabilities avoided per year and per million inhabitants. Thrombolysis within 3 hours with rt-PA can prevent 1 death or disability for 7 patients treated and, being applicable to 10\% of patients, avoids 34 deaths or disabilities per year, per million inhabitants. For the French population (66 million inhabitants), the organization of stroke units would avoid 7920 deaths or disabilities per year, and thrombolysis within 3 hours with rt-PA allow to avoid additional 2 244."

Researchers and stakeholders in the field of health have for several years now, invested this axis through various researches that have recently led to different laws (Note 3). From the 50s, various pilot tests were conducted to study the interest of a specific treatment of stroke. However, it is mainly from the 80s that randomized clinical trials have attempted to demonstrate the benefit of these units. These studies show that the stroke units are beneficial to individual and collective levels, even without thrombolysis, regardless of age, gender, type and severity of stroke (Stroke Unit Trialist Collaboration, 2001, 2007).

Table 1. Comparing Stroke Units and conventional care through randomized clinical trials over 1 year

\begin{tabular}{llll}
\hline & Stroke Unit & Control & OR over 1 year \\
\hline Death & $20.7 \%$ & $24.8 \%$ & $0.82(0.7-0.94)$ \\
Death or institutional & $39.9 \%$ & $45.3 \%$ & $0.80(0.7-0.9)$ \\
Death or disability* & $55.8 \%$ & $60.9 \%$ & $0.78(0.68-0.89)$ \\
$*$ : $\mathbf{m R S} 3-5 ; \mathbf{n}>\mathbf{4 ~ 0 0 0}$ & & & \\
\hline
\end{tabular}

Source: Stroke Unit Trialist Collaboration (2001, 2007). 
The economic aspect of stroke management can be measured through the average length of hospital stay which is the main indicator of the cost during the acute period (Hommel, Jaillard, \& Besson, 1999; Diringer et al., 1999). The specialized units enable a reduction in length of stay of almost $8 \%$, it is to say 0.3 days (confidence interval 95\% from -1.8 to 1.1 days) (Hommel et al., 1999; Bowen \& Yaste, 1994), reaching $40 \%$ in some series (Hommel, Memin, Besson, \& Perret, 1991; Jorgensen et al., 1995; Kalra, 1994; Wentworth \& Atkinson, 1996). The Cochrane meta-analysis reveals that for every 100 patients treated in a stroke unit, there is a reduction of 26 days. This reduction in the average length of hospital stay is attributed to better recovery and better organization of the output of the patients (Bowen \& Yaste, 1994; Kalra, Dale \& Crome, 1993).

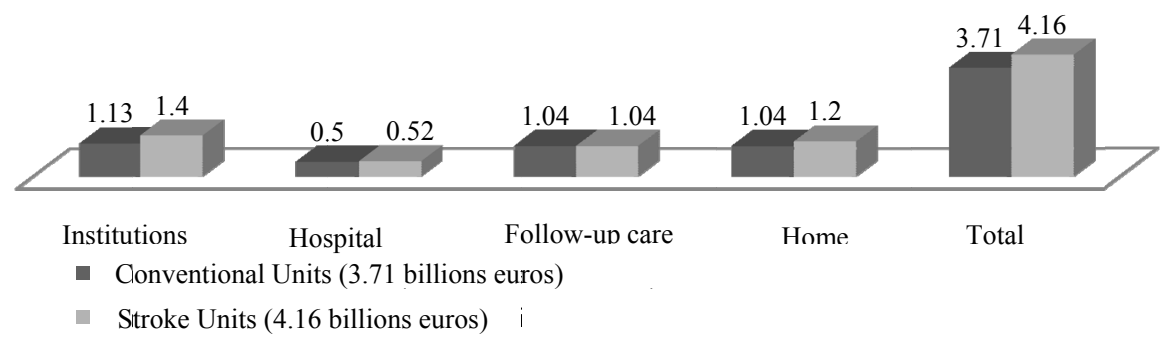

Figure 2. Total cost comparison between conventional and stroke units for 120,000 strokes (in billions of euros) Source: Launois et al. (2002).

In 2002, the National Agency for Accreditation and Evaluation in Health (ANAES, 2002) notes that the expected economic impact of the development of stroke units is insufficiently studied in literature. The findings of the international literature are not illuminating as to the length of stay, but suggest an increase in personnel expenses (related to more intensive supervision and early mobilization of patients). The data available in 2002 can not formally conclude: - about the short-term financial impact of the implementation of dedicated units, compared to conventional services - about the long-term impact, including costs attributable to residual disability of stroke patients. However, clinical data seem favorable on the long-term, since the dedicated units reduce the dependency ratio and / or institutionalization after stroke.

The public health challenge is to implement a rational therapeutic strategy as early as possible coordinating the different actors of the chain. If there is an added cost, it appears justified by the clinical benefits observed (Launois et al., 2002).

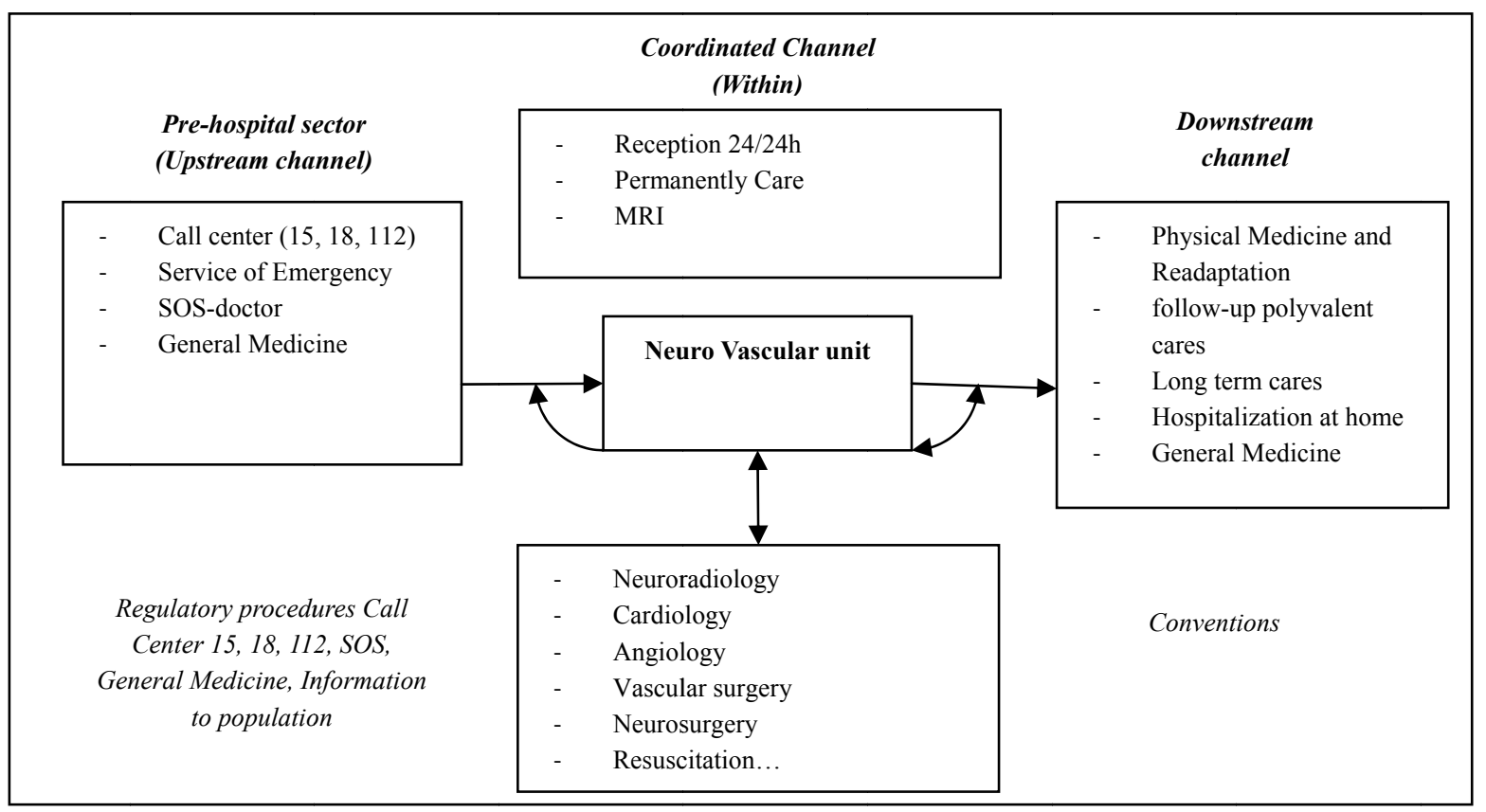

Figure 3. Neurovascular units as core of the stroke channel 
Since the question of the creation of specialized channels in the treatment of stroke (for an early care) is no longer standing, the focus is now needed on the organizational arrangements and the management of such channels. Indeed, according to SFNV (2001, p.1 451), the benefits due to such units is not based on the action of a drug, but on the effectiveness of an interactive multidisciplinary team.

Neurovascular Units are considered by the government as the model appropriated for the treatment of stroke. According to the circular DHOS 11.03.2003 and 03.22.2007, these units are dedicated to stroke care; they have a multidisciplinary team trained in neurovascular diseases. They coordinate the entire chain (upstream, within, downstream), with a reception 24/24 in direct admission. They have an MRI (Magnetic Resonance Imaging) and / or scanner 24/24, and can provide thrombolysis and other treatments of acute phase.

Despite a relatively advanced thinking on the development of these sectors, the note of ANAES (2002) points out that the channels upstream and downstream seem insufficiently structured, relying more on local agreements that on an organizational structure for the management of patients with stroke.

Bardet (2007) also emphasizes the need to better organize relief in an emergency stroke channel; coordinate the means through partnership development; install in each administrative region a technical committee in charge of the animation of the stroke channel.

Table 2. Distribution and density of stroke units in France

\begin{tabular}{|c|c|c|c|c|c|c|}
\hline Region & $\begin{array}{l}\text { Inhabitants } \\
\text { (INSEE } \\
\text { 2006) }\end{array}$ & $\begin{array}{l}\text { Stroke units } \\
\text { existing } 31 \\
\text { March } 2009 \\
\end{array}$ & $\begin{array}{l}\text { New Stroke } \\
\text { units for } \\
2009\end{array}$ & $\begin{array}{l}\text { Total at } \\
\text { the end } \\
\text { of } 2009\end{array}$ & $\begin{array}{l}\text { Density Stroke units / } \\
1000000 \text { inhab. 1st } \\
\text { quarter } 2009\end{array}$ & $\begin{array}{l}\text { Density Stroke } \\
\text { units / } 1000000 \\
\text { inhab. End of } 2009\end{array}$ \\
\hline Alsace & 1847604 & 3 & 1 & 4 & 1.62 & 2.16 \\
\hline Aquitaine & 3205490 & 2 & 5 & 7 & 0.62 & 2.18 \\
\hline Auvergne & 1379138 & 1 & & 1 & 0.73 & 0.73 \\
\hline Bourgogne & 1681293 & 1 & & 1 & 0.59 & 0.59 \\
\hline Bretagne & 3193598 & 4 & 4 & 8 & 1.25 & 2.51 \\
\hline Centre & 2591265 & 4 & 3 & 7 & 1.54 & 2.7 \\
\hline Champagne Ardenne & 1378356 & 1 & 2 & 3 & 0.73 & 2.18 \\
\hline Corse & 299542 & 0 & & 0 & 0 & 0 \\
\hline Franche Comté & 1187665 & 2 & 2 & 4 & 1.68 & 3.37 \\
\hline Ile de France & 11671585 & 16 & 2 & 18 & 1.37 & 1.54 \\
\hline Languedoc-Roussillon & 2589704 & 5 & & 5 & 1.93 & 1.93 \\
\hline Limousin & 753537 & 1 & & 1 & 1.33 & 1.33 \\
\hline Lorraine & 2391381 & 2 & 1 & 3 & 0.84 & 1.25 \\
\hline Midi-Pyrénées & 2855792 & 6 & 3 & 9 & 2.1 & 3.15 \\
\hline Nord Pas de Calais & 4088785 & 7 & 2 & 9 & 1.71 & 2.2 \\
\hline Normandie (Basse) & 1500300 & 2 & 2 & 4 & 1.33 & 2.67 \\
\hline Normandie (Haute) & 1851344 & 2 & 1 & 3 & 1.08 & 1.62 \\
\hline Pays de la Loire & 3553353 & 2 & 2 & 4 & 0.56 & 1.13 \\
\hline Picardie & 1942169 & 4 & 2 & 6 & 2.06 & 3.09 \\
\hline Poitou-Charentes & 1778856 & 2 & & 2 & 1.12 & 1.12 \\
\hline $\begin{array}{l}\text { Provence Alpes Côte } \\
\text { d'Azur }\end{array}$ & 4896850 & 4 & 2 & 6 & 0.82 & 1.23 \\
\hline Rhône Alpes & 6172369 & 7 & 1 & 8 & 1.13 & 1.3 \\
\hline $\begin{array}{l}\text { Total metropolitan } \\
\text { France }\end{array}$ & 62809976 & 78 & 35 & 113 & 1.24 & 1.8 \\
\hline
\end{tabular}

Sources: ARH and DHOS - April 2009.

Despite a significant increase in the implementation of stroke units in France, we observe a lag between the recommendations adopted by the government and the reality. In 1999, 22 stroke units were allowed to treat $4 \%$ of strokes. In 2007, 58 stroke units (11 in "Ile de France") have treated 15\% of strokes. This proportion of hospitalized strokes in specialized neurovascular units is the same in Italy but far stronger in Germany (30\%), Great Britain (36\%) or Scandinavian countries (60-70\%). The goal, for France, is now to cover $60 \%$ of strokes through 140 specialized units. 


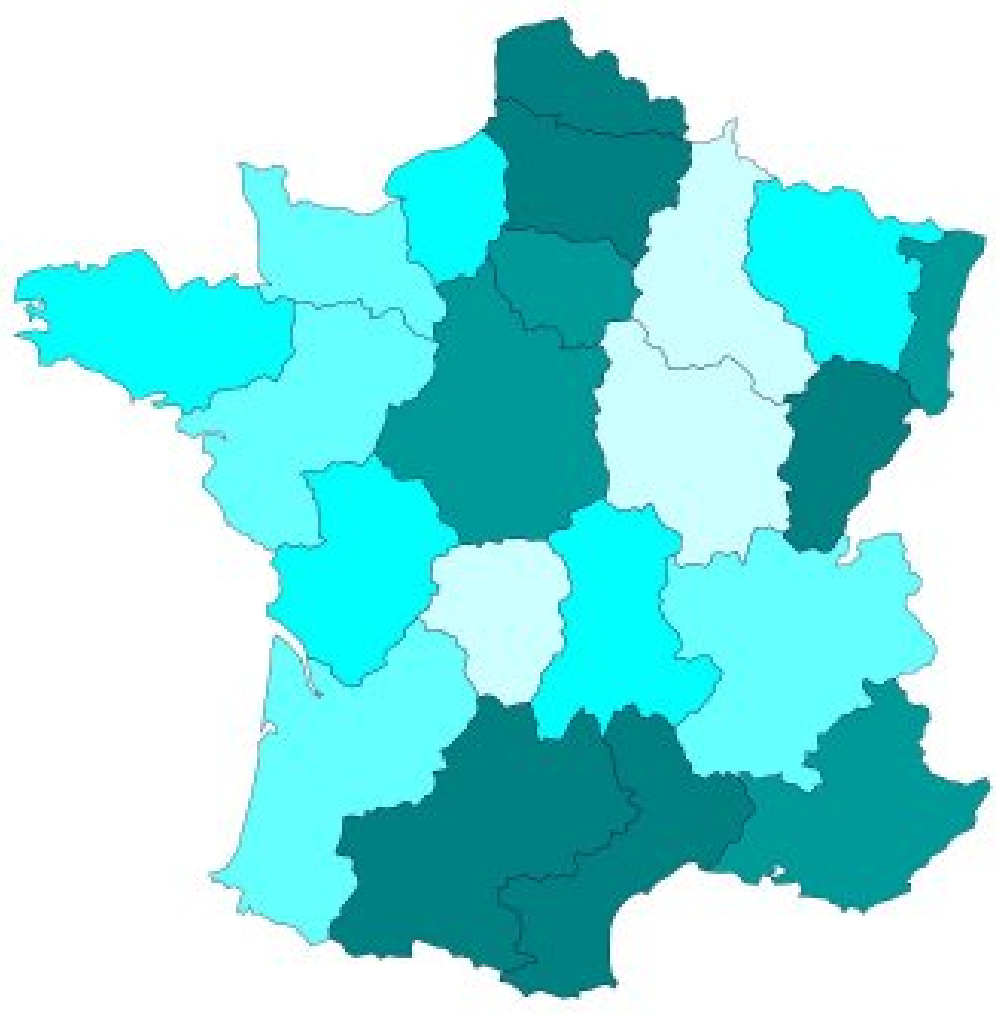

$[25.00 ; 32.80]$

$\{20.00 ; 25.00\}$

$115.00 ; 20.00$ |

$[10.00: 15.00$ [

$[0.00 ; 10.00[$

Figure 4. Regional mapping of CVA admitted in stroke centers (percentages in 4th quarter 2008) Sources: data PMSI 4th trimester 2008 - Atih / DHOS - listing of the stroke units: ARH and DHOS, Cartography DHOS/ 06.04.2009.

\section{Role of the Information System and Business Process Modeling Approach}

D. Elidrissi and A. Elidrissi (2010) define the information system (IS) as a consistent group of interlinked tasks in order to reach a specific goal: according to them, its first mission will thus be to inform people with reliable data. But according to Rochet (2010b), the main aim of the IS is to reflect the organization as a system. Though, Le Moigne and Bartoli (1996) work from the initial assumption that "the prime function of the IS of any organization is the recording in suitable forms of data, in other words multiform representations of multiple activities of this organization" (Note 4). These different definitions make us assume that it is important to conceive information systems that help the organizations to resolve their problems, often due to a complex environment. In other words, because a system is a network of desirable interactions between processes (Rochet, 2010b), it has to be agile. Then, one additional function of the Fire Department information system may be to provide a unique standard of data for all the organizations involved in the channel. That way, every process could be standardized and understood by every actor (Rochet, 2010b).

However, it seems we generally forget that if technology can be organized to help us to meet our needs, it is not a solution in itself. First, we must conceive and represent these needs to be able to use the technology to meet them. In the public sector, this tendency is even stronger because of specific constraints: the data are very heterogeneous, a lot of stakeholders are involved, there are often changes because of politics and environment, etc. That is partly why the public sector has not benefited from the technology as much as the private organizations. Besides, while in the private sector failures only impact the company and its stakeholders, in the public sector failures hurt all the society (Peneranda, Peignot, \& Rochet, 2012) and the consequences are strongly harmful: there is not only a loss of creation value but also a decrease of people confidence in their government, especially in a recession context. These authors, following Krob and Printz' example (2010), agree to say that the success of implementation of the technology in a public sector will be based on three pillars: 


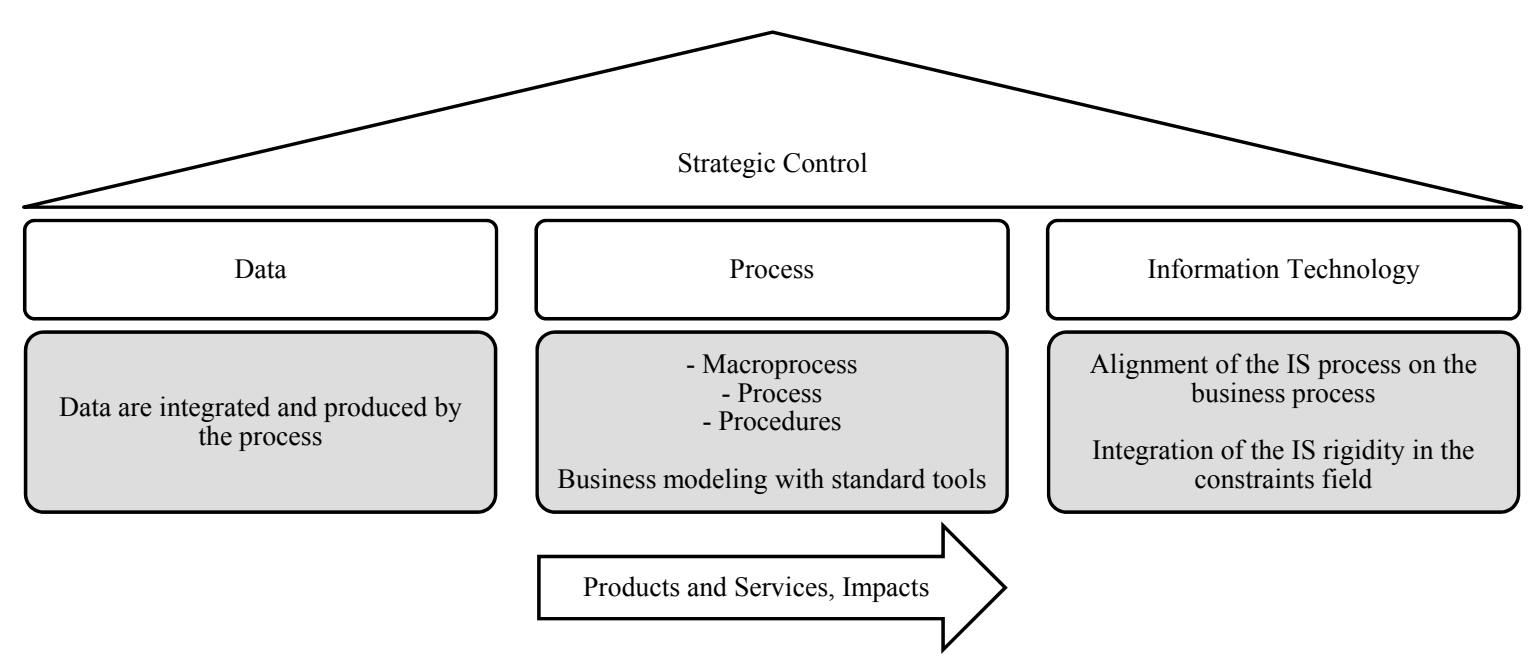

Figure 5. The three pillars of the organizational architecture

Source: inspired by Krob and Printz (2010) in Peneranda et al. (2012)

We understand that the central pillar is about the human and business processes. But what exactly is a process?

A business process is characterized by: inputs, outputs, an aim, resources, activities made in a precise order, and organizational and horizontal impacts (which will affect other processes of other services or organizations). A business process creates value for an internal or external customer.

To visualize the process and its functioning, we can refer to the"Crosby turtle":

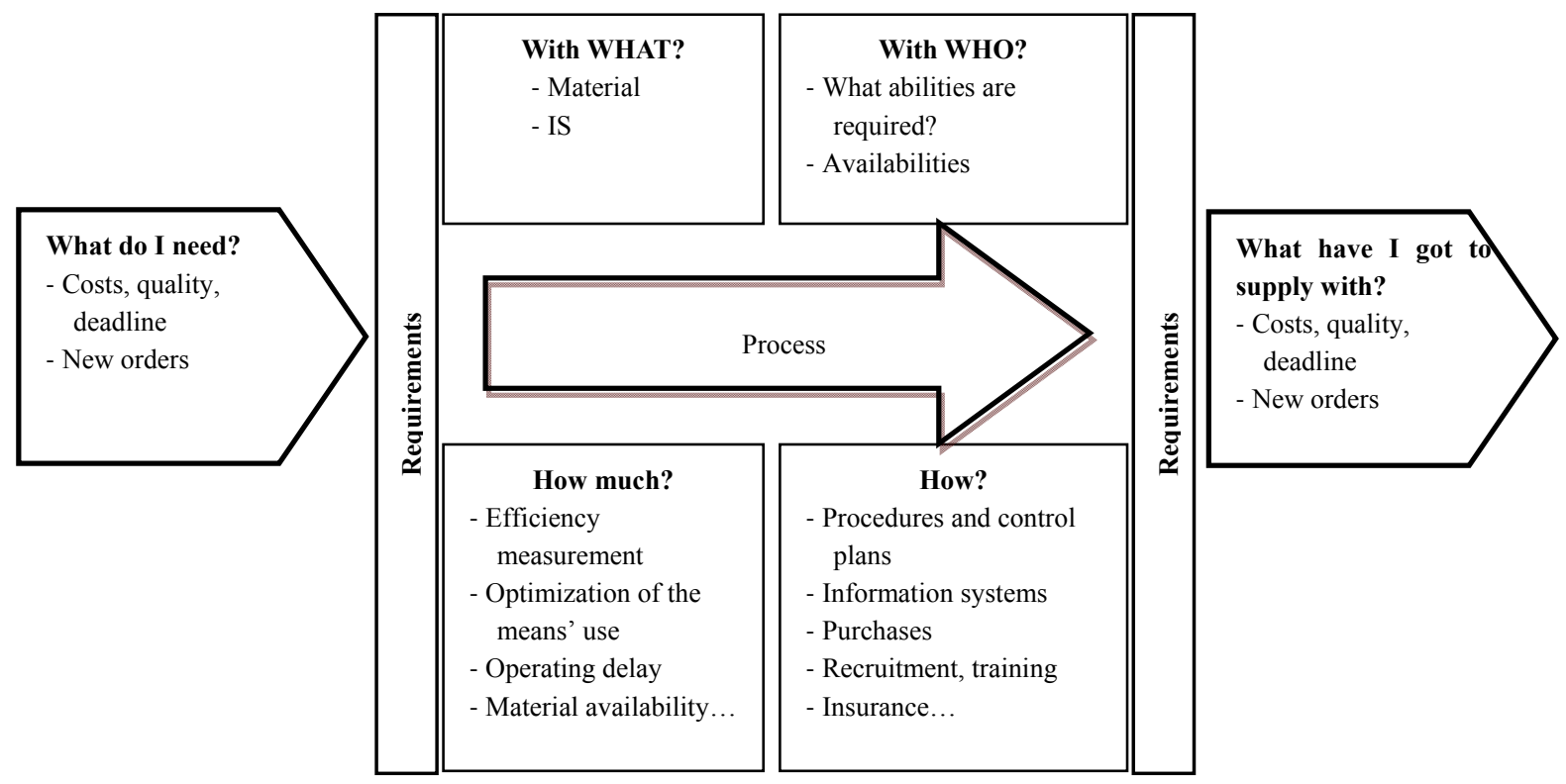

Figure 6. The Crosby turtle according to Rochet (2010b)

So a business process seems to be a set of activities assembled to produce specific outputs for specific customer(s). Consequently, process modeling involves a focusing on "how" doing the work rather than "what" is to be done. Thus a business process is a chain of work activities throughout time and space with a beginning, an end and clearly defined inputs and outputs. In other words, it is a "structure for action" (Sparx Systems, 2004).

Business processes can be modeled by using specific software (MEGA, Casewise, ARIS...) but these software only provide tools to draw the processes graphically: consequently, a first step will be the modeling of the processes by the humans, without using any hardware (Rochet, 2010b). Then, the digitalized processes will have to reflect what the humans initially draw; fortunately, the continual improving of information technology allows more and more flexibility in this practice (Peneranda et al., 2012). 
Nevertheless, Rochet (2010a) warns us about the data quality: it's an often careless point that modeling processes becomes useless if the data are not relevant and reliable. Indeed, data have their own life cycle. And an information system follows the rule "garbage in, garbage out"! Lastly, it is equally important to keep in mind that the information system is only a representation of the reality: uncertainties, due to human and technical dimensions, will always exist (Peneranda et al., 2012).

In the Fire Department of the Bouches du Rhône, the process modeling already started in a business process modeling (BPM) approach (Rochet, Kéramidas, Tiberghien, Agopian, \& Paris-Laporte, 2010). The BPM principle is based on a representation of the processes of an organization in order to be able to analyze the global system. For some authors, the BPM approach brings an internal innovation by its capability to translate real scenarios in operational processes (Peneranda et al., 2012). According to Rochet (2010a), the interest of this approach is to align the information technology and the different activities in the organization. It is above all a relevant methodology about process modeling because it allows to work on different levels of granularity (processes contain subprocesses, which contain procedures, etc.) (Rochet, 2010b). According to this author, the BPM approach has another asset: it enables us to build a meta-modeling to describe any process and thus to unite two performance necessities of an organization: a process-oriented vision and the structuring of this vision. These are two conditions of the value creation in an organization (Rochet, 2010b).

Once the process modeled, it will be necessary to extract indicators in order to measure the efficiency and the effectiveness of the process and its subprocesses. These indicators will have to be relevant, strategic, clear, reliable and calculated on a constant and transparent basis. They should be directly extracted from the information system to avoid human perception bias. The human judgment will only occur in the choice and the interpretation of the indicators (Rochet, 2010b).

This work recently leaded to a first global modeling of the CVA channel presented in figure 7.

\section{From Process Modeling to a Roadmap for Balanced Scorecard: Some Thinking about Performance Measurement \& Indicators}

This method has made it possible to obtain different indicators to begin an evaluation of the channel benefits:

- Impacts of the specific activities of the channel

- Specific costs

- Level of activities

Table 3. General indicators of the beginning of the stroke channel

\begin{tabular}{|c|c|c|}
\hline Impacts of specific activities & Specific costs & Level of activities \\
\hline $\begin{array}{l}\text { - After an awareness campaign, } \\
\text { calls of a specific pathology } \\
\text { approximately increase by } \mathbf{2 0 \%} \text {. }\end{array}$ & $\begin{array}{l}\text { - One patient of this channel } \\
\text { costs the SDIS } 200 € \\
\text { - For the hospital it represents } 1 \\
300 € \text { (treatment) and an } \\
\text { additional cost around } 300 € \text { for } \\
\text { neurologist supervision. Total: } \\
\text { around } \mathbf{1 8 0 0 €}\end{array}$ & $\begin{array}{l}\text { - In one year, on } \mathbf{1 2 0} \mathbf{0 0 0} \text { health emergency calls, around } \mathbf{6 0} \mathbf{0 0 0} \text { may } \\
\text { lead to the conference for three. } \\
\text { - On this } 60000 \text {, only around } \mathbf{6 0 0} \text { patients will launch the CVA } \\
\text { process. } \\
\text { - The SDIS of the Bouches du Rhône transported } \mathbf{3 8 0} \text { patients in this } \\
\text { channel in } 2011 \text { (the others can be brought by the SAMU or other } \\
\text { services) } \\
\text { - Around } \mathbf{2 0} \text { patients per month are treated while } 100 \text { are received to } \\
\text { the stroke center ( } 80 \text { cannot be treated). } \\
\text { - Duration of the patient stay in the hospital: around } \mathbf{5} \text { days for a } \\
\text { treated patient; around } \mathbf{3 0} \text { days for a non-treated one. } \\
\text { - Around } \mathbf{4} \text { or } \mathbf{5} \text { patients per month escape from the channel (because } \\
\text { of non-appropriate diagnostics for example) }\end{array}$ \\
\hline
\end{tabular}

Moreover, in 1999, Launois, Megnigbeto, Le Lay, Scart-Gres and Gaudin estimated the total cost for the health system of the 120000 strokes occurred in one year in France: around 2.5 Mds€ (17 milliards Francs in the article). Although we cannot consider this cost would be the same nowadays, it is interesting to have an overview of the distribution of this amount in different types of costs: 


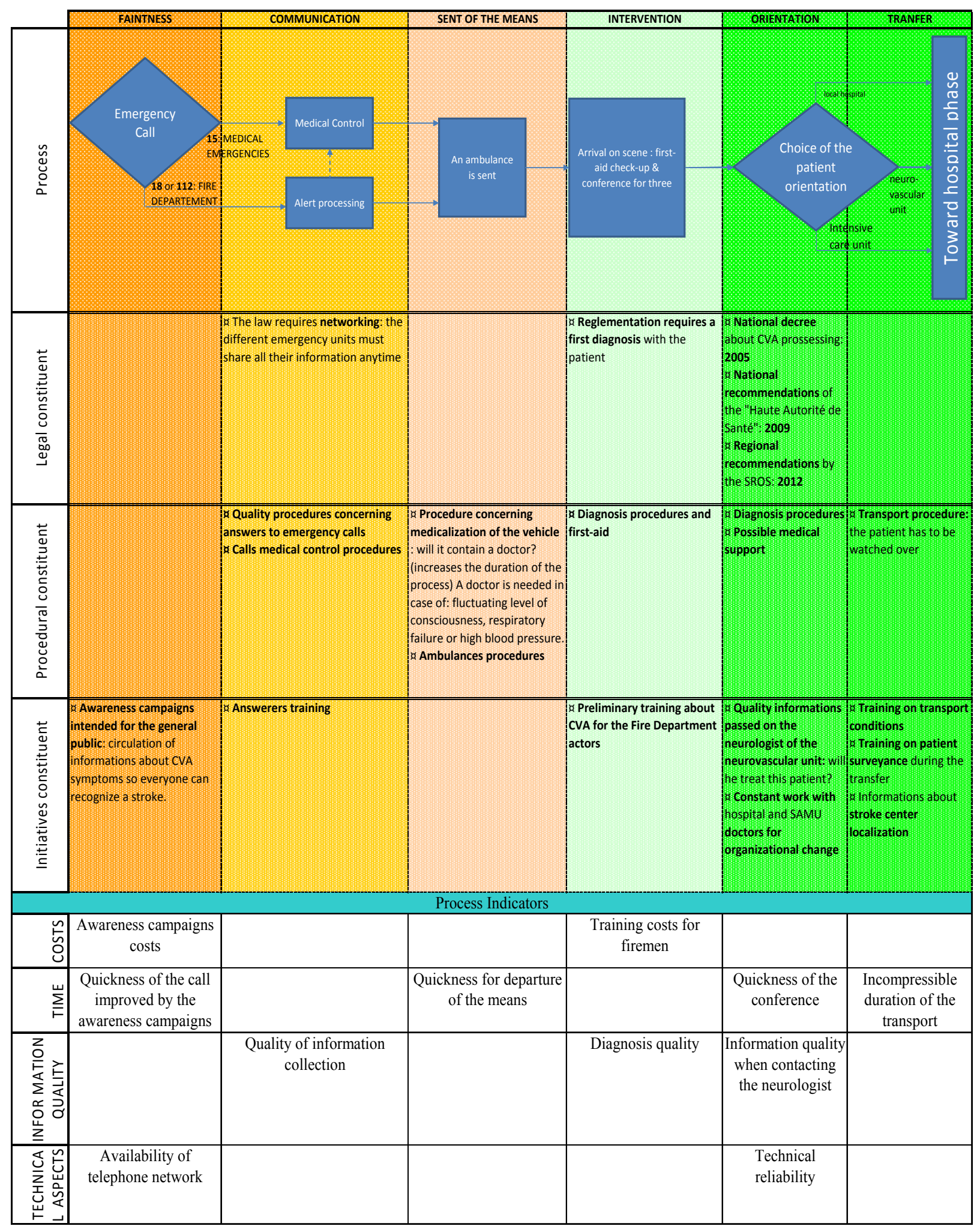

Figure 7. Summary table of the process modeling of the stroke center 


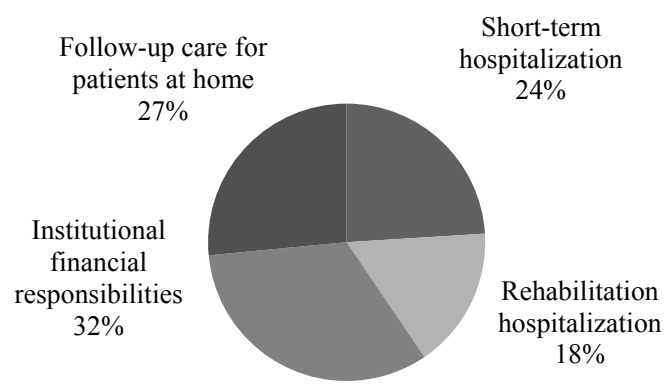

Figure 8. Repartition of the total cost of CVA according to Launois et al. (1999)

Besides, these authors noticed that the higher was the degree of disability, the higher were the cost per victim.

In 2002, the same authors managed to calculate that the cost of an untreated patient during 18 months stands at $18757 €$. So if we consider 150000 victims in year, we obtain $2.8 \mathrm{Mds} €$. On top of that, we can add that in ten years, the costs evolution has certainly been rising.

Though a balanced scorecard is required to pursue this work in order to correctly monitor the stroke channel, these first statistics allow us to draw positive conclusions. Indeed, this channel is characterized by specificities that require the actors to accept and deal with important constraints of time and cost, but it also leads to essential benefits for the treatable patient who will retrieve his entire faculties. In addition, we notice that the costs for the society are very high when someone gets permanently disabled. The balance between the costs of the channel and the costs of disabled people makes it clear that it is in the best interest of the French health system to invest in stroke channels; therefore the created value is obvious, both for the individual and the society.

Because of our conviction of the reproducibility of this channel, we are now able to conclude with a roadmap to build up and conduct such an undertaking. Here are our recommendations:

1) First of all, it clearly appeared in our observation of the channel and in the discussions with the actors that the crucial point in the functioning of the channel is the coordination needed between the different actors. Indeed, continuous adjustments are essential between the hospital, the stroke center, the SDIS and the hospital emergency services. Every individual in each organization often needed to discuss with another to negotiate his role, the information he received or passed. Missions are progressively modified and made more precise to optimize the functioning of the channel. Indeed, after having modeled the channel, the actors chose to strip it down. Notably, in case of stroke suspicions, intervention does not include a doctor anymore. Only first-aid workers are mobilized to gain time because the actors had correctly foreseen that the fewer intervening people there are, the faster the process is carried out. This kind of simplifications resulted in an organizational sea change since every actor has to question and often change his role in these specific interventions.

2) Then, the information quality also plays an important role at several levels of the channel: in the information collection of the first emergency call to recognize a stroke case, then about the diagnosis realized on scene and the information transmitted during the conference for three because it leads to the good (or bad) choice of orientation of the patient. This information quality must be improved by training different actors in the channel, as the operators who receive the emergency calls and the firemen who can be faced to a stroke in an intervention.

3) The training will of course play a critical role in recognizing the symptoms of a CVA and taking care of this kind of patient until he is in the hands of the stroke center. Different actions were done in this way: training courses, educational documents posted up in every Fire station, etc.

4) An important way of improving the channel can be to work on awareness campaigns to inform people about the symptoms and ways to treat a stroke. This may lead to a shortening of the duration of the process, which may increase the possibility to treat patients because of the four hours limit to practice a thrombolysis. However, if the awareness campaigns increase the number of calls for CVA, they seem to be effective for around four or five months only. Consequently, awareness campaigns will have to be repeated regularly to be really useful.

5) To obtain the support of the organizations and the local and national governments, it also will probably be necessary to inform the different institutions about the benefits of this channel with a clear balance between costs of treated and untreated patients. Indeed, the lack of support by the deciding organs could turn out to be a serious barrier to the success of such a project. 
6) At the edge, technical aspects may also have their importance: the technology level will have to permit the conference for three, for example, and networking between the emergency services.

\section{Conclusion}

Through this article, we proposed an overview of a real stroke channel built in the Bouches du Rhône, France. The aim of this study was to examine the interest of such a project and understand what are the key elements that enable the effective functioning of the channel. After explaining the ins and outs of the stroke centers, we have modeled the global process of the channel. This study allowed us to generate several first key indicators which are prior to a future balanced scorecard to monitor the channel. This scorecard will be the aim of next studies that are necessary to dig in depth into the subject.

However, from this preliminary work and thanks to observation and discussions with the actors of the channel, we managed to build a roadmap and recommendations to duplicate this kind of channel. Setting bridges between the different services and making them work together seemed to be a critical point to the channel, because it allowed to reduce the number of people who intervene and thus to considerably simplify the process. Training, information quality, awareness campaigns, technical aspects and institutions support were other considerable aspects of the success of this project. Finally, the channel could be completely extracted from its context to be implemented elsewhere.

Indeed, it is clear that this project can be reproducible as a framework in other rescue departments. Furthermore, we think this roadmap can be usedto implement other similar channels. For example, heart attacks could benefit from such a modeling approach: leading to coordination if, of course, its specific constraints and specificities are taken into account.

Nevertheless, one should keep in mind that this costs-benefits approach does not supplant the ethical aspect and advantages of this channel: if the benefits for the society can bring to light the value creation of the CVA channel, the main point of this project remains the lives it allows to save.

In addition, even if the channel is of strong interest for the society, it can be competing with other highly beneficial process: in a context of limited means, choice may be made between projects and some of them may never see the light of day. That's why we have presented this channel modeling as a useful tool for emergency services but without claiming it is the only solution. Our aim was more to highlight the organizational adjustments and changes the project has set in motion. Here, we think other disciplines, as organizational sociology or public policies analysis, could bring essential discussions which could lead to answers around actors' games in such processes and about efficiency of emergency channels. These are other future research paths which should not be ignored to improve understanding of health care systems in present-day societies. As such, this type of work needs to be integrated into a more global approach refocusing the health care system into its urban ecosystem.

\section{References}

Agence Nationale d'Accréditation et d'Evaluation en Santé [ANAES]. (2002). Place des unités neuro-vasculaires dans la prise en charge des patients atteints d'accident vasculaire cérébral. Service des recommandations Professionnelles et service évaluation économique.

Allard-Poesi, F., \& Maréchal, C. (2007). Construction de l'objet de la recherche. In R. A. Thiétart et al. (Eds.), Méthodes de Recherche en Management (pp. 34-57). Paris: Dunod.

Anonymous. (2005, May/July). Un outil de pointe pour les attaques cérébrales. Mistral soignant.

Avenier, M. J., \& Gavard-Perret, M. L. (2008). Inscrire son projet de recherche dans un cadre épistémologique. In M-L. Gavard-Perret et al. (Eds.), Méthodologie de la recherche, réussir son mémoire ou sa thèse en sciences de gestion (pp. 5-45). Pearson Education.

Bardet, J. (2007). Rapport sur la prise en charge précoce des accidents vasculaires cérébraux. Office Parlementaire d'Evaluation des Politiques de Santé.

Bowen, J., \& Yaste, C. (1994). Effect of a stroke protocol on hospital costs of stroke patients. Neurology, 44, 1961. http://dx.doi.org/10.1212/WNL.44.10.1961

Canaple, S., \& Depriester, C. (2006). Prise en charge des accidents cérébraux ischémiques à la phase aiguë. Urgence Pratique.

Canault, E., Castanier, L., Laude, J. F., Bonnefoi, B., \& Kiegel, P. (2006). Thrombolyse des AVC ischémiques dans un SAU. Urgence Pratique, $\mathrm{n}^{\circ} 76$. 
Charreire Petit, S., \& Durieux, F. (2007). Explorer et tester : les deux voies de la recherche. In R-A. Thiétart et al. (Eds.), Méthodes de Recherche en Management (pp. 58-83). Paris: Dunod.

Diringer, M. N., Edwards, D. F., Mattson, D. T., Akins, P. T., Sheedy, C. W., Hsu, C. Y., \& Dromerick, A. W. (1999). Predictors of acute hospital costs for treatment of ischemic stroke in an academic center. Stroke, 30, 724-8. http://dx.doi.org/10.1161/01.STR.30.4.724

Elidrissi, D., \& Elidrissi, A. (2010). Contribution des systèmes d'information à la performance des organisations: le cas des banques. La Revue des Sciences de Gestion. http://dx.doi.org/10.1051/larsg/2010006

Giordano, Y., \& Jolibert, A. (2008). Spécifier l'objet de la recherche. In M-L. Gavard-Perret et al. (Eds.), Méthodologie de la recherche, réussir son mémoire ou sa thèse en sciences de gestion (pp. 47-86). Pearson Education.

Hankey, G. J., \& Warlow, C. P. (1999). Treatment and secondary prevention of stroke: evidence, costs, and effects on individuals and populations. Lancet, 354, 1457-63. http://dx.doi.org/10.1016/S0140-6736(99)04407-4

Hommel, M., Jaillard, A., \& Besson, G. (1999). Filières de soins, unités d'urgences cérébrovasculaires. Rev Neurol (Paris), 155, 666-9.

Hommel, M., Memin, B., Besson, G., \& Perret, J. (1991). Hospital admission and acute stroke units. Cerebrovasc Dis, 1(suppl 1), 50-3. http://dx.doi.org/10.1159/000108897

Jorgensen, H. S., Nakayyama, H., Raaschou, O., Larsen, K., Hubbe, P., \& Olsen, T. S. (1995). The effect of a stroke unit: reduction in mortality, discharge rate to nursing home, length of hospital stay, and cost. A community-based study. Stroke, 26, 1178-82. http://dx.doi.org/10.1161/01.STR.26.7.1178

Journé, B. (2008). Collecter les données par l'observation. In M-L. Gavard-Perret et al. (Eds.), Méthodologie de la recherche, réussir son mémoire ou sa thèse en sciences de gestion (pp. 139-176). Pearson Education.

Kalra, L. (1994). The influence of stroke unit rehabilitation on functional recovery from stroke. Stroke, 25, 821-5. http://dx.doi.org/10.1161/01.STR.25.4.821

Kalra, L., Dale, P., \& Crome, P. (1993). Improving stroke rehabilitation: a controlled study. Stroke, 24, 1462-7. http://dx.doi.org/10.1161/01.STR.24.10.1462

Launois, R., Giroud, M., Megnigbeto, A. C., Mahagne, M. H., Le Lay, K., Présenté, G., . . Gaudin, A. F. (2002). L'accident vasculaire cérébral en France: Efficacité et coût des Unités Neuro-Vasculaires par rapport aux soins conventionnels. Réseau d'Evaluation en Economie de Santé.

Launois, R., Megnigbeto, A. C., Le Lay, K., Scart-Gres, C., \& Gaudin, A. F. (1999). Coût d'un suivi à 5 ans des AVC en fonction du degré d'autonomie et des structures de prises en charges. Econométrie de la santé XII.

Le Moigne, J. L., \& Bartoli, J. A. (1996). Organisation intelligente et système d'information stratégique. Economica.

Ministère de la santé. (2003). Circulaire DHOS/DGS/DGAS n²003-517 du 3 novembre 2003 relative à la prise en charge des accidents vasculaires cérébraux. p. 11.

Peneranda, A., Peignot, J., \& Rochet, C. (2012). Digitizing the organisation.

Rochet, C. (2010a). E-government and the modernization of public administration. $3^{\text {rd }}$ Euro Mediterranean Dialogue on Public Management, EGPA.

Rochet, C. (2010b). Politiques Publiques: de la stratégie aux résultats. De Boeck University.

Rochet, C., Kéramidas, O., Tiberghien, B., Agopian, P., \& Paris-Laporte, C. (2010). Management des services publics et pilotage de la performance: vision en contre-plongée de la Loi d'Orientation des Lois de Finances. Pyramides, revue du CERAP, Université Libre de Bruxelles, N¹9-2010/1, pp.203-217.

Société Française Neuro-Vasculaire [SFNV]. (2001). Recommandations pour la création d'Unités Neuro-Vasculaires. Rev Neurol (Paris), Masson, 157(11), 1447-1456.

Spark Systems. (2004). The Business Process Model, UML Tutorials. http://www.sparxsystems.com/downloads/whitepapers/The_Business_Process_Model.pdf

Stroke Unit Trialists' Collaboration. (2001). Organised inpatient (stroke unit) care for stroke. The Cochrane Database of Systematic Reviews, Issue 3, Art No CD000197. 
Stroke Unit Trialists' Collaboration. (2007). Organised inpatient (stroke unit) care for stroke. The Cochrane Database of Systematic Reviews, Issue 4, Art No CD000197.

Wentworth, D. A., \& Atkinson, R. P. (1996). Implementation of an acute stroke program decreases hospitalization costs and length of stay. Stroke, 27, 1040-3. http://dx.doi.org/10.1161/01.STR.27.6.1040

\section{Notes}

Note 1. Circular DHOS/DGS/DGAS n ${ }^{\circ} 2003-517$ of November, the $3^{\text {rd }}, 2003$.

Note 2. Magnetic Resonance Imaging.

Note 3. See especially the ministerial circulars from 11.03.2003 on the treatment of stroke, and 03.22.2007 on the role of stroke units in the treatment of stroke.

Note 4. The initial quotation is: "la fonction "primaire" du SI de toute organisation est l'enregistrement sous de formes adéquates des données, autrement dit des représentations multiformes des multiples activités de cette organisation.", p. 45.

Note 5. BPMI website: www.bpmi.org.

Note 6. French Health ministry about strokes statistics: http://www.sante.gouv.fr/les-chiffres-cles-de-l-avc.html.

Note 7. Service départemental d'incendie et de secours des Bouches du Rhône: www.sdis13.fr. 